\title{
Neuromuscular monitoring, residual blockade, and reversal: Time for re-evaluation of our clinical practice
}

\author{
Benoît Plaud, MD, PhD
}

Received: 25 March 2013/Accepted: 16 April 2013/Published online: 10 May 2013

(C) Canadian Anesthesiologists' Society 2013

\begin{abstract}
"Learn from yesterday, live for today, hope for tomorrow. The important thing is not to stop questioning." Albert Einstein (1879-1955)
\end{abstract}

Even with the advent of shorter-acting muscle relaxants, the risk of residual blockade continues to persist. Consequently, in daily practice, we are confronted with the following contradiction, namely, how best to combine muscular relaxation throughout the operative procedure without exposing patients to the risk of residual blockade at the end of the case. A Continuing Professional Development (CPD) module concerning residual blockade is published in this issue of the Journal. ${ }^{1}$ Why was it necessary to publish a CPD module on this topic when a number of related studies and surveys reports are already available? While many clinicians are convinced about the benefits of both neuromuscular monitoring and reversal in current practice, nevertheless, reality seems to differ. Anesthesiologists are well trained in the use of neuromuscular blocking agents. In fact, anesthesiology is the only specialty where these drugs are routinely used. And yet, many clinicians tend not to follow the basic recommendations for using both neuromuscular monitoring and reversal agents. The circumstances leading to this state of affairs are likely more complex. The last updated version of the American Society of Anesthesiologists' (ASA) Practice Guidelines for Postanesthetic

Benoît Plaud is consultant for MSD ${ }^{\mathrm{TM}}$ France and $\mathrm{MSD}^{\mathrm{TM}}$ International and has participated in the clinical development of sugammadex $\left(\right.$ Bridion $\left.^{\circledR}\right)$.

B. Plaud, MD, PhD ( $\varangle)$

Paris-Est Créteil University \& Assistance Publique-Hôpitaux de Paris, Department of Anesthesia and Surgical Intensive Care, University Hospital Albert Chenevier - Henri Mondor, 94010 Créteil, France

e-mail: benoit.plaud@hmn.aphp.fr
Care states that: "Assessment of neuromuscular function primarily includes physical examination and, on occasion, may include neuromuscular blockade monitoring". ${ }^{2}$ With such an assertion regarding the potential for occasional use of neuromuscular monitoring, it would, in all likelihood, be difficult to convince our colleagues regarding the benefits of neuromuscular monitoring and modify existing behaviour. Clinical methods for determining signs of residual blockade may not have the degree of sensitivity to detect partial paralysis. For example, residual paralysis is likely in patients who are able to maintain a sustained head lift. ${ }^{3}$ It is only with objective neuromuscular monitoring that one can exclude residual blockade. ${ }^{1}$ Clearly, the ASA Task Force on Postanesthetic Care developed their recommendation based on data lacking in sufficient evidence. ${ }^{2}$ This is also the basis for $\mathrm{SpO}_{2}$ monitoring. Pedersen et al. from the Cochrane Collaboration updated the systematic review on the use of pulse oximetry during the perioperative period. ${ }^{4}$ The authors' conclusions are comparable with two previous reviews published by the same group. Even if the use of pulse oximetry helped decrease the frequency of hypoxemic episodes, it does not influence patient outcome on major end points (e.g., death and cardiovascular, respiratory, or neurological complications). Even when we consider these evidence-based data on pulse oximetry, can any one of us imagine starting a case without its use? This depiction reveals the limits of evidence-based medicine. This topic has previously been addressed with humour in a study on whether or not there are benefits to using a parachute to prevent death during free fall. ${ }^{5}$

Residual blockade remains a specific concern in daily anesthesia practice. The use of neuromuscular blocking drugs has facilitated major progress in performing additional and more complex surgical procedures. This view was first addressed by Dr. Harrold Griffith et al. 70 years ago when 
they published a case series on the clinical use of nondepolarizing agents in abdominal surgery. ${ }^{6}$ The authors concluded with a premonition: "It seems to us, as the result of these preliminary clinical investigations, that curare may prove to be a drug that will occasionally be of great value, and will give us a means of providing the surgeon rapidly with excellent muscular relaxation at critical times during certain operations". It was then possible to offer a better surgical field without deepening anesthesia. In fact, muscle relaxants had lower hemodynamic effects compared with the anesthetic agents (e.g., barbiturates, cyclopropane) available during that time period. This anesthesia technique was popularized in Europe by Gray et al. and became well known as the concept of balanced anesthesia, which consists of subtle fine-tuning of equilibrium between hypnosis, analgesia, and neuromuscular blockade. ${ }^{7}$ This concept remains a cornerstone of our daily practice. Of course, the hemodynamic effects of more recent drugs are less pronounced, and monitors can now assess the depth of anesthesia; nevertheless, the basic concept remains the same. In a retrospective study published in 1954, two American surgeons, Beecher and Todd, challenged this assertion. They showed that the use of muscle relaxants increased the anesthesia death rate. ${ }^{8}$ When muscle relaxants were used, the mortality rate related to anesthesia (1:370 anesthetic procedures) was six times greater than the mortality rate when muscle relaxants were avoided (1:2,100 anesthetic procedures). This result is not surprising as there was no mention whether or not they made use of reversal agents. This was not the case in the Griffith et al. series. When they mentioned: "Since prostigmine is used as an antidote to curare, an ampule of this drug should always be available", 6 it is likely that they used a reversal agent.

Over the past forty years, both anesthesia-related mortality and severe morbidity, including permanent brain damage, have decreased dramatically. This issue has been confirmed both in France ${ }^{9}$ and in the USA. ${ }^{10}$ Anesthesiology is often cited as a model of safety in healthcare. ${ }^{11}$ At present, with the anesthesia-associated mortality rate at $\sim 1 / 10^{5}$, anesthesia is one of the safest human disciplines in modern healthcare. What will be the next step to approach the level of safety achieved in other human activities, e.g., commercial aeronautics ${ }^{12}$ Due to its direct influence on patient outcome, the anesthesia team likely remains the central element in this next step. ${ }^{13,14}$ New developments may not necessarily emerge from new drug discoveries or from innovative devices; instead, they may likely emerge from an understanding of human factors or behaviours. As mentioned by Leape et al., it has become increasingly clear that, in the short term, we can improve the health status and life expectancy of the population simply by applying what we know rather than by developing new treatments. ${ }^{15}$ This is the precise aim of the CPD module published in this issue, that is, to expose the current knowledge justifying the use of neuromuscular monitoring and reversal. ${ }^{1}$ To reach this objective and put it into practice, anesthesia team members must be actively involved, and their behaviour should be guided by fundamental safety rules. ${ }^{16}$ Neily et al. have shown that use of a multifaceted intervention of medical team training, involving teamwork training, ongoing coaching, and checklists to trigger operating room briefings and debriefings, can result in an associated reduction in mortality. ${ }^{17}$

Anesthesia has largely contributed to the development of surgery due to improvements in safety, both in terms of process (preoperative evaluation, delivery of anesthesia, and postoperative care) and improvements in drug safety (short onset and offset, minimal cardiovascular effects). How could the developments in major abdominal surgery have been envisioned without the use of curare in general anesthesia? ${ }^{6}$ Nowadays, there may not be a need for new anesthetic drugs. The key issue is: The way in which we use the current anesthesia drug during the procedure can influence the outcome. Due to the sense of patient safety acquired over the last four decades, the consequences of misusing anesthetic agents, including neuromuscular blocking drugs, may have been underestimated, especially in the absence of appropriate monitoring. This issue is now regularly reported in the literature. The risks encountered during the course of anesthesia were underlined in a recent study, specifically, the unfavourable combination of low blood pressure, low bispectral index, and low minimum alveolar concentration of volatile anesthesics. ${ }^{18}$ Sessler et al. attempted to show how the manner in which anesthesia is conducted can have a major impact on outcome. ${ }^{19}$ This issue was addressed a few years ago in a study by Arbous et al. who clearly showed that just following the guidelines (e.g., monitoring, and checklists) and adhering to good clinical practices (e.g., reversal of residual paralysis, pain control) can have a major impact on anesthetic outcome (e.g., death or permanent brain damage). ${ }^{14}$

Donati clearly exposes the current knowledge on residual blockade and the strategies to prevent and treat it. ${ }^{1}$ His key message is that residual blockade is a frequent occurrence, even with short-acting drugs or after a administering a single bolus of curare; it is a source of significant severe morbidity but is managed relatively easily with objective neuromuscular monitoring and reversal agents. Valuable strategies to prevent residual blockade include avoidance of long-acting muscle relaxants, use of iterative injections rather than continuous infusion to maintain neuromuscular blockade, prevent hypothermia, use of objective neuromuscular monitoring during the procedure, and use of reversal agents at the end of the case. In one case scenario presented in the CPD module, access to the patient's hands and feet is restricted because of the surgical requirements. ${ }^{1}$ When confronted with a challenging situation such as this, should one administer a 
muscle relaxant and reversal agent without neuromuscular monitoring? In this situation, it was possible to use a simple nerve stimulator to monitor the patient's degree of relaxation at the eyebrow throughout the procedure and to wait for access to the patient's hands to evaluate the degree of residual blockade and administer neostigmine at the appropriate time. This case represents a real life situation. It remains important to use neuromuscular monitoring even when it can sometimes be difficult to perform. However, the usefulness of intraoperative neuromuscular monitoring to reduce the frequency of residual paralysis on arrival in the postanesthesia care unit (PACU) remains a matter of debate. The results of a meta-analysis indicated that the use of an intraoperative neuromuscular function monitor was not associated with a decrease in the rate of residual paralysis; ${ }^{20}$ despite, that study included results of a number of uncontrolled trials. Therefore, if evidence-based medicine reports contradictory results regarding the impact of using neuromuscular monitoring, one must keep in mind that neuromuscular monitoring is an integral part of good clinical practice that simplifies the management of muscle relaxants and facilitates the timing to administer reversal agents. Even though it is not possible to conclude that certain monitors, such pulse oximetry and $\mathrm{CO}_{2}$ monitors, can directly improve the outcome of patients on major end points, monitoring, whatever the variable, can serve as a guide for a medical strategy, facilitate dosage adjustment, and anticipate potential complications (i.e., residual curarization). Adequate neuromuscular recovery, defined as an adductor pollicis train-offour (TOF) ratio $\geq 0.9$, requires quantitative evaluation of TOF ratio using methods of measurement in clinical practice such as acceleration or displacement (kinemyography). To be clinically acceptable, these methods must have excellent reproducibility and must be simple to use. There are numerous criticisms regarding the use of neuromuscular monitoring, including poor repeatability, difficult to set up, and low durability with intensive use. ${ }^{21,22}$ All these criticisms are probably justified. Objective tests of neuromuscular recovery can be applied to the awake patient in the PACU, but the response is not as reliable as in anesthetized subjects because TOF ratio measurements can be affected by spontaneous movements of the thumb. Therefore, the TOF ratio value would probably be inaccurate. To avoid imprecision, the message would be to use the neuromuscular monitor in the operating room rather than in the PACU where the patient is fully awake, as the stimulation could induce discomfort and where measurement could be affected by arm movement. As with all monitors, we should correctly interpret the particular resulting variable (e.g., TOF ratio measurement). We must use a monitor as a guide for a previously defined medical strategy. The use of monitoring in our specialty, particularly pulse oximetry and end-tidal $\mathrm{CO}_{2}$ monitoring, has contributed to a dramatic decrease in anesthesia-related mortality and severe morbidity, particularly permanent brain damage, even without randomized controlled trials. Why haven't we implemented the use of neuromuscular monitors and reversal in our practice? This question remains unanswered to date. Cabana et al. have provided some explanations, for example, the lack of knowledge dissemination (delayed or unavailable information), the "own" demeanour of physicians (disagreement, skeptical, lack of motivation), and the constraints (lack of time or equipment). ${ }^{23}$ All surveys performed worldwide show the same trend concerning neuromuscular monitoring and reversal. They continue to be underused. Another explanation concerning neuromuscular monitoring may relate to the absence of technical support in this field. It is important to recognize the considerable effort put forth by industry to improve both the reliability and ease of use of certain monitors (e.g., pulse oximetry, ultrasound technology). This has not been the case with neuromuscular monitors. Nevertheless, because neither clinical signs nor fixed time intervals are suitable criteria for management of neuromuscular blockade, objective assessment of the degree of relaxation is crucial. Without this process, misdoses could inevitably occur and result in insufficient depth of neuromuscular blockade or drug cumulation during the procedure.

In addition to the risk of residual blockade and its management, the underlying and likely key issue is the medical strategy during tracheal extubation. Compared with numerous available data evaluating different strategies to manage the difficult airway, there are relatively few studies focused on the peri-extubation period. The important issue is probably how to extubate the patient's trachea safely and rapidly as soon as the procedure has ended. There are many prerequisites to accomplishing this procedure, such as use of hypnotics and opioids with optimal kinetic properties, control of hemodynamic variables and maintenance of normothermia, correct set up and use of neuromuscular monitoring, anticipating analgesic requirements. At the end of the procedure, the stage will have been set to reverse the residual blockade under "residual" anesthesia with subsequent measurement of TOF ratio in a stable situation.

Aligned with the CPD module published in this issue of the Journal, we should revisit and put into practice the fundamental aspects of neuromuscular management, and in particular, methods to avoid residual blockade as well as methods for the safe administration of reversal agents. Let us implement this important aspect of knowledge translation into our daily routine clinical practice. Yes indeed, it is now time for another re-evaluation of current practice of monitoring and reversal. We encourage readers to read and to complete the related CPD module in this issue. 


\section{Monitorage}

neuromusculaire, curarisation résiduelle et neutralisation: I'heure de réévaluer notre pratique clinique

"Apprenez du passé, vivez pour le présent, espérez. pour le futur. L'important, c'est de ne jamais cesser de se questionner. » Albert Einstein (1879-1955)

En dépit de la disponibilité de curares à durée d'action intermédiaire, le risque de curarisation résiduelle demeure réel. C'est pourquoi, dans notre pratique quotidienne, nous sommes confrontés à la contradiction suivante: quelle est la meilleure façon d'obtenir un bon relâchement musculaire tout au long de l'opération sans exposer notre patient au risque de curarisation résiduelle à la fin de l'intervention? Un module de Développement professionnel continu (DPC) portant sur la curarisation résiduelle est publié dans ce numéro du Journal. ${ }^{1}$ Pourquoi avons-nous jugé nécessaire de publier un module de DPC à ce sujet, puisqu'il existe déjà plusieurs études et comptes rendus de sondages traitant de cette question? Alors que nombre de cliniciens sont convaincus des bienfaits du monitorage neuromusculaire et de la neutralisation dans la pratique actuelle, la réalité semble néanmoins bien différente. La formation des anesthésiologistes en matière de curares est excellente. En fait, l'anesthésiologie est la seule spécialité qui utilise de façon systématique ces médicaments. Pourtant, de nombreux cliniciens ont tendance à ne pas respecter les recommandations de base quant à l'utilisation du monitorage neuromusculaire et des agents de neutralisation. Les circonstances menant à cet état de fait sont probablement complexes. La dernière version mise à jour du Guide d'exercice des soins postanesthésiques de l'American Society of Anesthesiologists (ASA) déclare: "L'évaluation de la fonction neuromusculaire inclut principalement l'examen physique et, à l'occasion, pourrait inclure le monitorage de la curarisation $»^{2}$ Avec une telle déclaration quant à la possibilité d'une utilisation occasionnelle du monitorage neuromusculaire, il n'est pas étonnant qu'il soit difficile de convaincre nos collègues des avantages du monitorage de la curarisation et de modifier les comportements actuels. Les méthodes cliniques permettant d'identifier les signes de curarisation résiduelle pourraient ne pas avoir suffisamment de sensibilité pour détecter une curarisation partielle. Par

Benoît Plaud est consultant pour MSD ${ }^{\mathrm{TM}}$ France et $\mathrm{MSD}^{\mathrm{TM}}$ International et a participé à la mise au point clinique du sugammadex $\left(\right.$ Bridion $^{\circledR}$ ). exemple, la curarisation résiduelle est probable chez les patients qui peuvent maintenir leur tête soulevée. ${ }^{3}$ Seul le monitorage neuromusculaire objectif permet d'exclure une curarisation résiduelle. ${ }^{1}$ Il est évident que le Groupe de travail sur les soins postanesthésiques de l'ASA a émis sa recommandation en se fondant sur des données insuffisamment probantes. ${ }^{2}$ C'est également le cas du monitorage de la $\mathrm{SpO}_{2}$. Pedersen et coll., du groupe de Collaboration Cochrane, ont mis à jour la revue méthodique sur l'utilisation de l'oxymétrie de pouls en période périopératoire. ${ }^{4}$ Les conclusions des auteurs sont comparables à celles de deux synthèses précédentes publiées par le même groupe: même si l'utilisation de l'oxymétrie de pouls a permis de réduire l'incidence des épisodes d'hypoxémie, cette mesure n'influence aucunement le pronostic du patient quant aux pronostics majeurs (par ex. la mort ou les complications cardiovasculaires, respiratoires ou neurologiques). Ceci étant dit, même quand nous prenons connaissance de tels résultats fondés sur des données probantes, peut-on imaginer commencer un cas sans utiliser d'oxymètre de pouls? Cet exemple illustre bien les limites de la médecine factuelle. Ce sujet a déjà été traité avec humour dans une étude examinant s'il y avait des avantages - ou non - à utiliser un parachute pour prévenir le décès pendant une chute libre. $^{5}$

La curarisation résiduelle demeure une préoccupation spécifique à la pratique quotidienne de l'anesthésie. L'utilisation de curares a permis de faire des progrès majeurs en réalisant plus d'interventions chirurgicales supplémentaires et d'une complexité plus grande. Cette opinion a d'abord été émise par le Dr Harrold Griffith et coll. il y a 70 ans, lorsqu'ils publiaient une série de cas sur l'utilisation clinique d'agents non dépolarisants pour les chirurgies abdominales. ${ }^{6}$ Les auteurs concluaient leur article sur une prémonition: «Il nous semble, en conséquence de ces recherches cliniques preliminaires, que les curares pourraient s'avérer des médicaments qui auront occasionnellement une grande valeur, et qu'ils nous donneront un moyen de fournir rapidement au chirurgien un excellent relâchement musculaire à des moments critiques pendant certaines opérations ». Il était alors possible d'offrir un meilleur champ opératoire sans approfondir l'anesthésie. En fait, les curares avaient des effets hémodynamiques plus faibles que les agents anesthésiques (par ex. les barbituriques, le cyclopropane) disponibles à cette époque. Gray et coll. ont popularisé cette technique d'anesthésie, bien connue en tant que concept d'anesthésie balancée, en Europe, qui consiste à créer un subtil équilibre entre hypnose, analgésie et curarisation. ${ }^{7} \mathrm{Ce}$ concept demeure une pierre angulaire de notre pratique quotidienne. Bien entendu, les effets hémodynamiques des médicaments plus récents sont moins prononcés, et il existe aujourd'hui des moniteurs pour évaluer la profondeur de l'anesthésie, mais le concept de base est le même. Dans une étude rétrospective publiée en 1954, deux chirurgiens américains, Beecher et Todd, ont mis en doute cette idée. Ils ont montré que l'utilisation de curares augmentait le taux de 
mortalité liée à l'anesthésie. ${ }^{8}$ Lorsque des curares étaient utilisés, le taux de mortalité liée à l'anesthésie (1:370 anesthésies) était multiplié par six par rapport au taux de mortalité lorsqu'on n'utilisait pas de curare (1:2100 anesthésies). Ce résultat n'est pas surprenant, étant donné qu'aucune mention n'est faite de l'utilisation (ou non) d'agents de neutralisation. Tel n'était pas le cas dans la série de Griffith et coll., car lorsqu'ils écrivent: "Étant donné qu'on utilise de la prostigmine comme antidote au curare, une ampoule de ce médicament devrait toujours être disponible », 6 on peut en déduire qu'ils ont probablement utilisé un agent de neutralisation.

Au cours des quarante dernières années, la mortalité et la morbidité sévère liées à l'anesthésie, y compris les lésions cérébrales permanentes, ont drastiquement chuté. Cette situation a été confirmée en France ${ }^{9}$ et aux États-Unis. ${ }^{10}$ L'anesthésiologie est souvent citée comme modèle de sécurité dans les soins de santé. ${ }^{11}$ À l'heure actuelle, le taux de mortalité associée à l'anesthésie étant situé à $\sim 1 / 10^{5}$, l'anesthésie est l'une des disciplines humaines les plus sécuritaires dans les soins de santé modernes. Quelle sera la prochaine étape pour s'approcher du niveau de sécurité atteint dans d'autres activités humaines, comme par exemple dans l'aviation commerciale? ${ }^{12}$ En raison de son influence directe sur les devenirs des patients, l'équipe d'anesthésie demeure probablement l'élément central de cette prochaine étape. ${ }^{13,14}$ Les progrès ne vont pas nécessairement se faire grâce à la découverte de nouveaux médicaments ou à la mise au point de dispositifs innovants. Ils pourraient voir le jour grâce à une nouvelle compréhension des facteurs ou des comportements humains. Comme le mentionnent Leape et coll., il est de plus en plus clair que nous pouvons améliorer, à court terme, l'état de santé et l'espérance de vie de la population en appliquant simplement nos connaissances plutôt qu'en mettant au point de nouveaux traitements. ${ }^{15}$ Voilà précisément l'objectif du module de DPC publié dans ce numéro: exposer les connaissances actuelles justifiant l'utilisation du monitorage de la curarisation et de la neutralisation. ${ }^{1}$ Pour atteindre cet objectif et le mettre en pratique, les membres de l'équipe d'anesthésie doivent s'impliquer activement, et leur comportement devrait se baser sur des règles de sécurité fondamentales. ${ }^{16}$ Neily et coll. ont montré que le recours à des interventions à plusieurs facettes touchant la formation de l'équipe médicale, comprenant la formation au travail en équipe, une assistance professionnelle continue et des listes de contrôle pour inciter l'équipe à échanger l'information avant et après l'intervention, pouvait entraîner une réduction associée de la mortalité. $^{17}$

L'anesthésie a joué un rôle important dans l'évolution de la chirurgie grâce aux progrès en matière de sécurité, tant en termes de processus (évaluation préopératoire, administration de l'anesthésie, et soins postopératoires) qu'en termes d'améliorations du profil de sécurité des médicaments (délai et durée d'action plus courts, effets cardiovasculaires moindres). Comment les progrès réalisés dans les chirurgies abdominales majeures auraient-ils pu être imaginés sans l'utilisation des curares en anesthésie générale? ${ }^{6}$ De nos jours, il se pourrait qu'on n'ait pas besoin de nouveaux agents anesthésiques. La problématique clé est que la façon dont nous utilisons les agents anesthésiques actuels pendant l'intervention peut avoir un impact sur le pronostic. En raison des préoccupations quant à la sécurité des patients qui se sont développées au cours des quarante dernières années, les conséquences d'une mauvaise utilisation des agents anesthésiques, y compris des curares, pourraient avoir été sous-estimées, particulièrement en l'absence d'un monitorage adapté. Ce problème est aujourd'hui rapporté régulièrement dans la littérature. Les risques encourus pendant l'anesthésie ont été soulignés dans une étude récente, plus spécifiquement, la combinaison néfaste d'une tension artérielle basse, d'un indice bispectral bas, et d'une concentration alvéolaire minimale basse d'agents anesthésiques volatils. ${ }^{18}$ Sessler et coll. ont tenté de montrer comment la façon dont l'anesthésie est réalisée peut avoir un impact majeur sur le pronostic. ${ }^{19}$ Cette question a été abordée il y a quelques années dans une étude de Arbous et coll., qui ont clairement démontré que le simple fait de suivre les recommandations (par ex. en utilisant le monitorage et les listes de contrôle) et de respecter les bonnes pratiques cliniques (par ex., en neutralisant la curarisation résiduelle et en contrôlant la douleur) pouvait avoir un impact majeur sur l'évolution du patient après une anesthésie (par ex. le décès ou les lésions cérébrales permanentes). ${ }^{14}$

Le Dr Donati expose clairement les connaissances actuelles concernant la curarisation résiduelle et les stratégies pour la prévenir et la traiter. ${ }^{1}$ Son message principal est que la curarisation résiduelle survient fréquemment, même avec des agents à durée d'action intermédiaire ou après l'administration d'un seul bolus de curare; est une source de morbidité grave importante, qu'elle est facile à prendre en charge à l'aide du monitorage objectif de la curarisation et de la neutralisation. Parmi les stratégies utiles pour prévenir la curarisation résiduelle, citons le fait d'éviter les curares à durée d'action prolongée, l'utilisation d'injections répétées plutôt que d'une perfusion continue pour maintenir la curarisation, la prévention de l'hypothermie, l'utilisation de monitorage quantitatif pendant l'intervention, et l'utilisation d'agents de neutralisation à la fin de la chirurgie. Dans le cas clinique présenté dans le module de DPC, l'accès aux mains et aux pieds de la patiente est restreint en raison des contraintes chirurgicales. ${ }^{1}$ Lorsqu'on est confronté à une situation délicate telle que celle-ci, devrait-on administrer un curare et un agent de neutralisation sans monitorage neuromusculaire? Dans ce cas précis, il a été 
possible d'utiliser un simple neurostimulateur pour estimer le degré de relâchement de la patiente au sourcil tout au long de l'intervention, puis d'attendre d'avoir accès aux mains de la patiente pour évaluer le degré de curarisation résiduelle et administrer la néostigmine au moment adéquat. Ce cas illustre une situation réaliste. Il est important d'utiliser des neurostimulateurs, même lorsque cela est difficile. Toutefois, l'utilité du monitorage de la curarisation en peropératoire afin de réduire la fréquence de curarisation résiduelle à l'arrivée en salle de réveil demeure contestée. Les résultats d'une méta-analyse indiquent que l'utilisation d'un moniteur de la fonction neuromusculaire pendant l'opération n'a pas été associée à une réduction du taux de curarisation résiduelle ${ }^{20}$ cette étude incluait les résultats de plusieurs études non contrôlées. Par conséquent, si la médecine factuelle rapporte des résultats contradictoires quant à l'impact du monitorage neuromusculaire, il convient de garder à l'esprit que ce type de monitorage fait partie intégrante des bonnes pratiques cliniques qui simplifient l'utilisation des curares et facilitent la prise de décision concernant le moment opportun pour administrer des agents de neutralisation. Bien qu'il ne soit pas possible de déterminer que certains moniteurs, tels ceux de l'oxymétrie de pouls et du $\mathrm{CO}_{2}$, puissent avoir un impact positif direct sur les pronostics majeurs des patients, le monitorage, quelle que soit la variable qu'il surveille, peut servir de guide pour mettre en place une stratégie médicale, faciliter l'adaptation posologique, et anticiper les complications potentielles (par ex., la curarisation résiduelle). Une récupération neuromusculaire adéquate, définie en tant qu'un rapport de train-de-quatre (TDQ) $\geq 0,9$ à l'adducteur du pouce, requiert une évaluation quantitative du rapport de TDQ se fondant sur des méthodes de mesure cliniques telles que l'accélération ou le déplacement (cinémyographie). Pour être acceptables d'un point de vue clinique, ces méthodes doivent posséder une excellente reproductibilité et être faciles à utiliser. Il existe de nombreuses critiques concernant l'utilisation du monitorage de la curarisation, en raison notamment de sa reproductibilité médiocre, de sa difficulté de mise en place, et de son peu de robustesse lors d'utilisation intensive. ${ }^{21,22}$ Toutes ces critiques sont probablement justifiées. Des tests objectifs de récupération neuromusculaire peuvent être appliqués au patient éveillé en salle de réveil, mais la réponse n'est pas aussi fiable que chez un patient anesthésié; en effet, les mesures du rapport de TDQ peuvent être affectées par les mouvements spontanés du pouce. C'est pourquoi la valeur du rapport de TDQ sera probablement inexacte. Afin d'éviter ces imprécisions, il serait souhaitable d'utiliser le moniteur neuromusculaire en salle d'opération plutôt qu'en salle de réveil lorsque le patient est tout à fait éveillé, la stimulation pouvant occasionner de l'inconfort et les mesures pouvant être affectées par les mouvements du bras. Comme pour tout moniteur, il est important d'interpréter correctement la variable spécifique qui en découle (par ex., la mesure du rapport de TDQ). Nous devons utiliser un moniteur pour guider une stratégie médicale définie au préalable. Dans notre spécialité, l'utilisation de moniteurs, et tout particulièrement de moniteurs de l'oxymétrie de pouls et de la $\mathrm{CO}_{2}$ télé-expiratoire, a contribué à une réduction draconienne de la mortalité et de la morbidité sévère liées à l'anesthésie, particulièrement des lésions cérébrales permanentes et ce, même sans études randomisées contrôlées. Dès lors, pourquoi n'avons-nous pas instauré l'utilisation de neurostimulateurs et l'administration d'un agent décurarisant dans notre pratique? À ce jour, cette question demeure sans réponse. Cabana et coll. ont proposé quelques explications, comme par exemple le manque de diffusion des connaissances (informations périmées ou non disponibles), le comportement des médecins (désaccord, scepticisme, manque de motivation), et les contraintes (manque de temps ou d'équipement). ${ }^{23}$ Tous les sondages réalisés dans le monde montrent la même tendance quant au monitorage de la curarisation et à la neutralisation: ils sont toujours sous-exploités. Une autre explication quant au peu d'utilisation du monitorage de la curarisation pourrait être liée à l'absence de soutien technique dans ce domaine. Il est important de reconnaître les efforts considérables de l'industrie pour améliorer la fiabilité et la convivialité de certains moniteurs (par ex., l'oxymétrie de pouls, l'échographie); cependant, ces efforts n'ont pas été observés dans le cas des moniteurs de la curarisation. Ainsi, étant donné que les signes cliniques et l'administration à intervalles de temps fixes ne sont pas des critères adaptés pour gérer la curarisation, l'évaluation objective du degré de relâchement musculaire est cruciale. Sans ce processus, un mauvais dosage pourrait inévitablement survenir et causer une profondeur de curarisation insuffisante ou, au contraire, une accumulation de médicaments pendant l'intervention.

Outre le risque de curarisation résiduelle et sa prise en charge, le problème sous-jacent, voire le problème clé, a trait à la stratégie médicale pendant l'extubation trachéale. Comparativement aux nombreuses données disponibles évaluant diverses stratégies pour prendre en charge des voies aériennes difficiles, il existe relativement peu d'études examinant la période entourant l'extubation. La question importante touche probablement à la façon d'extuber la trachée d'un patient en toute sécurité et rapidement, dès que l'intervention est terminée. Il existe de nombreux prérequis à la réalisation de cette manœuvre, comme l'utilisation d'agents hypnotiques et d'opiö̈des possédant des propriétés pharmacocinétiques optimales, le contrôle des variables hémodynamiques et le maintien de la normothermie, la mise en place et l'utilisation correctes du monitorage de la curarisation, et la prévision des besoins analgésiques. À la fin de l'intervention, la scène sera posée pour neutraliser la curarisation sous anesthésie 'résiduelle', 
en mesurant par la suite le rapport de TDQ dans une situation stable.

En ligne avec le module de DPC publié dans ce numéro du Journal, il est temps de revoir et d'appliquer les aspects fondamentaux de la prise en charge de la curarisation, en particulier les méthodes permettant d'éviter la curarisation résiduelle et celles touchant à l'administration sécuritaire d'agents de neutralisation. Cette composante importante du transfert des connaissances doit trouver sa place dans notre pratique clinique quotidienne. En effet, il est temps de procéder à une autre réévaluation de la pratique actuelle du monitorage et de la neutralisation. Nous encourageons les lecteurs à lire et compléter le module de DPC dans ce numéro.

\section{References}

1. Donati $F$. Residual paralysis: a real problem or did we invent a new disease? Can J Anesth 2013; 60: this issue. DOI: 10.1007/ s12630-013-9932-8.

2. Apfelbaum JL, Silverstein JH, Chung FF, et al. Practice guidelines for postanesthetic care: an updated report by the American Society of Anesthesiologists Task Force on Postanesthetic Care. Anesthesiology 2013; 118: 291-307.

3. Kopman AF, Yee PS, Neuman GG. Relationship of the train-offour fade ratio to clinical signs and symptoms of residual paralysis in awake volunteers. Anesthesiology 1997; 86: 765-71.

4. Pedersen T, Moller AM, Hovhannisyan K. Pulse oximetry for perioperative monitoring. Cochrane Database Syst Rev 2009; 4: CD002013.

5. Smith GC, Pell JP. Parachute use to prevent death and major trauma related to gravitational challenge: systematic review of randomised controlled trials. BMJ 2003; 327: 1459-61.

6. Griffith HR, Johnson E. The use of curare in general anesthesia. Anesthesiology 1942; 3: 418-20.

7. Gray TC, Halton J. A milestone in anaesthesia? (d-Tubocurarine chloride). Proc R Soc Med 1946; 39: 400-10.
8. Beecher HK, Todd DP. A study of deaths associated with anesthesia and surgery: based on a study of 599,548 anesthesias in ten institutions. Ann Surg 1954; 140: 2-35.

9. Lienhart A, Auroy $Y$, Prquignot F, et al. Survey of anesthesiarelated mortality in France. Anesthesiology 2006; 105: 1087-97.

10. Li G, Warner M, Lang BH, Huang L, Sun LS. Epidemiology of anesthesia-related mortality in the United States: 1999-2005. Anesthesiology 2009; 110: 759-65.

11. Lagasse RS. To see or not to see. Anesthesiology 2006; 105: 1071-3.

12. Amalberti $R$, Auroy $Y$, Berwick $D$, Barach $P$. Five system barriers to achieving ultrasafe health care. Ann Intern Med 2005; 142: 756-64.

13. Silber JH, Kennedy SK, Even-Shoshan O, et al. Anesthesiologist direction and patient outcomes. Anesthesiology 2000; 93: 152-63.

14. Arbous MS, Meursing AE, van Kleef JW, et al. Impact of anesthesia management characteristics on severe morbidity and mortality. Anesthesiology 2005; 102: 257-68.

15. Leape L, Berwick D, Clancy C, et al. Transforming healthcare: a safety imperative. Qual Saf Health Care 2009; 18: 424-8.

16. Pronovost PJ, Freischlag JA. Improving teamwork to reduce surgical mortality. JAMA 2010; 304: 1721-2.

17. Neily J, Mills PD, Young-Xu Y, et al. Association between implementation of a medical team training program and surgical mortality. JAMA 2010; 304: 1693-700.

18. Kheterpal S, Avidan MS. "Triple low" murderer, mediator, or mirror. Anesthesiology 2012; 116: 1176-8.

19. Sessler DI, Sigl JC, Kelley SD, et al. Hospital stay and mortality are increased in patients having a "triple low" of low blood pressure, low bispectral index, and low minimum alveolar concentration of volatile anesthesia. Anesthesiology 2012; 116: 1195-203.

20. Naguib M, Kopman AF, Ensor JE. Neuromuscular monitoring and postoperative residual curarisation: a meta-analysis. $\mathrm{Br} \mathrm{J}$ Anaesth 2007; 98: 302-16.

21. Baillard C, Bourdiau S, Le Toumelin P, et al. Assessing residual neuromuscular blockade using acceleromyography can be deceptive in postoperative awake patients. Anesth Analg 2004; 98: 854-7.

22. Fuchs-Buder T, Sirieix D, Schmartz D, Plaud B. Monitoring of neuromuscular block by acceleromyography: concepts, applications and limits of use (French). Ann Fr Anesth Reanim 2012; 31: 922-5.

23. Cabana MD, Rand CS, Powe NR, et al. Why don't physicians follow clinical practice guidelines? A framework for improvement. JAMA 1999; 282: 1458-65. 